\title{
The Effectiveness of the Use of Sign Language Videos in Improving the Behavior of Dental and Oral Health Care in Children with Impairment in SLB Negeri 1 Jambi City, Indonesia
}

\author{
Ervon Veriza* ${ }^{1}$, Hendry Boy ${ }^{2}$, Syukra Alhamda ${ }^{3}$, Pahrur Razi ${ }^{4}$ \\ ${ }^{1,4}$ Department of Health Promotion, Polytechnic of Health Jambi, Ministery of Health, Indonesia \\ ${ }^{2}$ Department of Dental Health, Polytechnic of Health Jambi, Ministery of Health, Indonesia \\ ${ }^{3}$ Department of Dental Health, Polytechnic of Health Padang, Ministery of Health, Indonesia
}

*Corresponding Author: Ervon Veriza, Department of Health Promotion, Polytechnic of Health Jambi, Ministery of Health, Indonesia.

\begin{abstract}
Deaf children are part of children with special needs. Deaf/speech impaired experience verbal communication problems due to loss of all or part of their hearing power, so they use sign language in communicating, therefore association with normal people experiences obstacles. According to WHO data, there are 32 million deaf children. Their limitations in hearing and speaking is one of the obstacles for deaf children to gain knowledge about oral and dental health, which in turn will determine attitudes and behaviors in maintaining dental and oral health.

This type of research is a quasi-experimental research model with a one-group pretest-posttest design research design. The research objective was to determine the effectiveness of sign language videos in improving oral health care behavior. The research method used a pre and post-test with the Wilcoxon test, a sample of 30 deaf children in SLB Negeri 1 Jambi City.
\end{abstract}

The results showed that the mean value was different between the behavior of maintaining dental health in the pre-test condition and the behavior of maintaining dental health in the post-test condition. This means that statistically, it indicates that there is a difference in the behavior of maintaining oral health before and after the screening of sign language videos regarding the maintenance of oral health. With the Wilcoxon statistical test, it was obtained a p-value of 0.61, meaning $p>0.05$, indicating that sign language video playback was not effective in improving the maintenance of oral health in children with hearing impairment.

Keywords: Sign language videos, deaf, oral health maintenance

\section{INTRODUCTION}

The implementation of health development is based on humanity, balance, benefits, protection, respect for rights and obligations, justice, gender, non-discrimination, and religious norms. (Ministry of Health, 2010). According to WHO data in 2014, about 360 million people in the world have hearing problems, namely 328 million in adults and 32 million in children. This limitation in hearing and/or speaking is one of the obstacles for deaf people to gain knowledge about oral and dental health which will determine children's attitudes and actions in maintaining oral hygiene ${ }^{1}$.

Basic Health Research Data the proportion of disabilities in children 5-17 years old by province, Jambi Province, there are 3669 children with disabilities including deaf children who live in urban and rural areas. Disability in children is aimed at measuring the achievement of the SDGs, which is one of the goals of the SDGs is to ensure a healthy life and promote welfare for all people in the world of all ages.

Children with special needs namely children with physical and mental limitations who have limited physical developmental conditions, behavior, or emotions. Children with special needs are one of the human resources of the Indonesian nation whose quality must be improved so that they can play a role, not only as objects of development but also as subjects of development. Children with disabilities need to be recognized and identified from the group of children in general, because they need special health services, such as medical services, special education, and certain exercises that aim to reduce limitations and dependence due to the disorder they suffer and foster independent community life. 
Deaf children are part of children with special needs. Deaf/speech impaired experience verbal communication problems due to loss of all or part of their hearing power, so they use sign language in communicating, therefore association with normal people experiences obstacles. They have ego-centric traits that exceed normal children, are quick to anger and irritability. Physical health is generally the same as other normal children. Deaf children have little or no sound experience obtained from their sense of hearing, the lack of mastery of the vocabulary of objects they have is one of the factors causing the low ability of deaf children to communicate, so they must use sign language in communicating. This limitation in hearing and speaking is one of the obstacles for deaf children in gaining knowledge about oral health which will later determine their attitudes and behavior in maintaining/maintaining the cleanliness of their teeth and mouth ${ }^{1}$.

Dental health is an integral part of overall health which can affect the quality of life. The prevalence of dental caries and periodontal disease is high in society and the results of the study show a wide impact, namely disruption to quality of life, including limited function, physical disability, psychological discomfort, and disability ${ }^{2}$. The results of the study by Sadimin et al., 2018 showed that the knowledge, attitudes, and actions of parents about oral health had a significant relationship with oral health (DMF-T) of deaf children with a p-value of 0.003 ( $p<0.05)$. In deaf children the process of understanding in reading will be hampered, the process of understanding received through images or video applications is more acceptable to deaf children.

Learning media is very important to use because it looks at the conditions and needs of children, especially deaf children who prioritize visuals to capture information. Learning media has many uses such as clarifying messages so that they are not too verbal but can also be captured through visuals. Visual-based media is very suitable for deaf children because deaf children are often referred to as visual or visual people as a result of their hearing loss ${ }^{3}$.

SLB Negeri I Jambi City is one of the longestrunning SLBs in Jambi City which was founded in 1981 with a land area of $1,400 \mathrm{M}^{2}$, the location is on Jalan Sersan M. Yunus RT.24 Kelurahan The Hok, South Jambi District, Jambi City, the number of students is \pm 286 people and educators who have abilities by the specifics of children with special needs. From the results of the preliminary survey, the school dental health business had never been carried out by a public health center, and there had never been any education on dental and oral health for children with special needs, including children with hearing impairment. From the results of the direct examination, there were 7 students whose mouths were still dirty and there were some caries because around the school there were many snacks that the students usually bought during recess. The results of interviews with several teachers there, deaf children prefer to learn with the media of images and videos that are shown to them slowly, such as the results of Edyati's research, 2014, namely counseling with video media is a medium that is following the characteristics of elementary school children who like fun and the desire to know something new.

At this time there is still a lack of learning media to increase the knowledge of deaf children in special schools in the form of videos for maintaining dental and oral health using sign language, with this background, the researchers are interested in examining whether the effectiveness of using sign language video media can improve oral health care behavior in deaf children.

\section{Material And Method}

This research is quasi-experimental research. The design of this study used a one-group pretest-posttest design. The purpose of this study was to determine the difference in the effectiveness of the video on the behavior of maintaining dental health in children with hearing impairment. The population of this research is children with hearing impairment. The sampling technique was purposive sampling based on the sample taken, from certain characteristics or characteristics, namely deaf children in SLB Negeri 1 Jambi City.

Data collection techniques in this study used a checklist sheet for brushing behavior, and a questionnaire for food behavior and oral health control. During pre, deaf children were previously observed on how to brush their teeth one by one by the researcher, then after brushing their teeth the children were directed to fill out a questionnaire that had been made, then given treatment by inviting the children to watch videos about how to maintain oral health, giving video 3 times with an interval of 10 minutes to repeat showing the video so that the deaf child 
The Effectiveness of the Use of Sign Language Videos in Improving the Behavior of Dental and Oral Health Care in Children with Impairment in SLB Negeri 1 Jambi City, Indonesia

can understand, then at the time of the post the next day just observed again how to brush their teeth and fill out the questionnaire again. PHP-M.

\section{RESULT}

In this study, it was observed that the behavior of maintaining oral health in children with hearing impairment before and after screening sign language videos about the maintenance of oral health obtained the following results:

In this study, it was observed that the behavior of maintaining oral health in children with hearing impairments before and after screening sign language videos about the maintenance of oral health obtained the following results:

Characteristics of Respondents
Research respondents totaled 30 deaf elementary school children who were willing and cooperative in the implementation of the research, Deaf children were elementary school children in grades 4,5, and 6 because these children could read and began to understand sign language.

Average score of deaf children's oral health care behavior.

In this study, the behaviors of maintaining oral health in children with hearing impairment were observed before and after the sign language video screening about the maintenance of oral health. Before the statistical test was carried out, the data normality test was conducted first using the Shapiro-Wilk statistical test.

Table1. Results of Normality Test for Teeth and Oral Health Care in Deaf children before and after the sign language video showing on the maintenance of oral and dental health

\begin{tabular}{|l|c|c|c|}
\hline \multicolumn{1}{|c|}{ Variabel } & \multicolumn{3}{|c|}{ Shapiro-Wilk } \\
\hline & Statistic & Df & Sig. \\
\hline Dental Health Maintenance Behavior (Pre-test) & .947 & 30 & .144 \\
Dental Health Maintenance Behavior (Post-test) & .960 & 30 & .304 \\
\hline
\end{tabular}

Remarks *) Significant at $>0.05$.

Based on Table 1, shows that the results of the Shapiro-Wilk statistical test showed that the significance value of the behavior of maintaining oral health both at the pre-test and post-test was greater than 0.05 . This means that the data on the behavior of maintaining dental health during the pre-test and post-test are normally distributed. Therefore, the statistical difference test used the Dependent t-test on paired data.

Table2. Average Score of Dental and Oral Health Care Behavior in children with hearing impairment before and after the sign language video screening about the maintenance of oral and dental health

\begin{tabular}{|c|c|c|c|c|}
\hline Variable & Maintenance & Mean & Std. Deviation & Min - Max \\
\hline Behavior maintenance & Pre-test & 3,37 & 1,83 & $0-8$ \\
of oral health & Post-test & 5,87 & 2,29 & $2-10$ \\
\hline
\end{tabular}

Based on Table 2, shows that the mean value is different between the behavior of maintaining dental health in the pre-test condition and the behavior of maintaining dental health in the post-test condition. This means that mathematically it indicates that there are differences in the behavior of maintaining dental and oral health before and after the treatment of sign language videos on the maintenance of dental and oral health.

Table3. Average Improvement of Dental and Oral Health Care Behavior in children with hearing impairment before and after sign language video screenings on the maintenance of oral and dental health

\begin{tabular}{|l|c|c|c|}
\hline \multirow{2}{*}{ Variable } & \multicolumn{2}{|c|}{ Average Score } & \multirow{2}{*}{$\begin{array}{c}\text { Average } \\
\text { Enhancement }\end{array}$} \\
\cline { 2 - 3 } & Before & After & 2,50 \\
\hline Behavior Health maintenance teeth and mouth & 3,37 & 5,87 & 2,57 \\
\hline
\end{tabular}

Based on Table 3, shows that there is an increase in the average score of the behavior of oral health care in children with hearing impairment before and after the sign language video playback about the maintenance of oral health by 2.50 .
The Effectiveness of Dental and Oral Health Care Behavior in children with hearing impairment before and after the sign language video screening on the maintenance of oral and dental health 
The Effectiveness of the Use of Sign Language Videos in Improving the Behavior of Dental and Oral Health Care in Children with Impairment in SLB Negeri 1 Jambi City, Indonesia

Table4. The Effectiveness of Dental and Oral Health Care Behavior in children with hearing impairment before and after the sign language video screening on the maintenance of oral and dental health

\begin{tabular}{|l|l|c|c|c|}
\hline \multicolumn{1}{|c|}{ Variable } & Maintenance & Mean & Std. Deviation & p-value \\
\hline Behavior maintenance of oral & Pre-test & 3,37 & 1,83 & 0,0001 \\
health & Post-test & 5,87 & 2,29 & \\
\hline
\end{tabular}

Remarks *) Significant at>0.05.

Based on Table 4, shows that sign language video playback is effective in improving the maintenance of oral health in children with hearing impairment.

\section{DISCUSSION}

1. Average scores of deaf children's dental and oral health care behavior before and after the sign language video screening about the maintenance of oral and dental health

From the results of the study, Table 2 shows that the mean value is different between the behavior of maintaining dental health in the pre-test condition and the behavior of maintaining dental health in the post-test condition. This means that this indicates that there are differences in the behavior of maintaining dental and oral health before and after the screening of sign language videos about maintaining oral health. These results are in line with research conducted by Widasari ${ }^{4}$ which shows that there are differences in knowledge before and after being given oral health education using sign language video methods and lectures at SDLB Patrang, Jember Regency.

Changes in individual scores from the pretest and posttest scores can be caused by, among other things, educational aids (demonstrations) using sign language videos. These props are structured based on the principle that the knowledge that is in every human being is received or captured through the five senses to facilitate perception ${ }^{5}$, even though deaf children have hearing and speech deficiencies but by watching videos they can receive information/knowledge through their eyes. because according to the theory of language that is based on sight and movement, deaf children will easily respond to it. From the results of this study, there was a change in the behavior of brushing teeth in deaf children, namely the behavior of brushing the tongue after brushing the teeth (attached to the parent table) from not brushing the tongue before seeing the video then brushing the tongue after seeing the sign language video. Deaf people are individuals who have barriers to good hearing ${ }^{6}$. To maximize the use of the senses and increase knowledge of dental and oral health, dental health education is needed with methods that can attract interest and maximize the use of the senses in students. The eyes are the most dominant sense for deaf children. So it is very important to determine a visual health education method for deaf children who tend to use their sense of sight to receive information and learn new things.

1. Average Improvement of Teeth and Oral Health Care Behavior in children with hearing impairment before and after the sign language video screening on the maintenance of oral and dental health

Table 3 shows that there is an increase in the average score of dental and oral health care behavior in children with hearing impairment before and after sign language videos about maintaining oral and dental health by 1 . This is in line with the results of research conducted by Widasari $^{4}$ that the dental and oral health education using the sign language video method and sign language lectures had the effect of increasing students' knowledge in SDLB Patrang, Jember Regency.

The method of teaching dental and oral health care using sign language can improve the behavior of maintaining oral health in children with hearing impairment. Based on the opinion of Mhaske $^{7}$ said that according to deaf children, sign media is an appropriate way to compensate for children's hearing loss, because deaf children have hearing loss, as a substitute for hearing that functions as a language receiver, they need signs as a substitute. The extension can work optimally if it is carried out with methods, media, material messages, and extension workers who can work harmoniously so that it can be said to be effective ${ }^{8}$.

2. The Effectiveness of Dental and Oral Health Care Behavior in children with hearing impairment before and after the sign language video showing on the maintenance of oral and dental health

From the results of the study, Table 4 shows that sign language video playback is not effective in improving the maintenance of oral health in deaf 
The Effectiveness of the Use of Sign Language Videos in Improving the Behavior of Dental and Oral Health Care in Children with Impairment in SLB Negeri 1 Jambi City, Indonesia

children with a value of $\mathrm{p}=0.061$, meaning $\mathrm{p}>$ 0.05 . This research is in line with the research results of Putri ${ }^{9}$ that the oral health of children with special needs is lower than normal children, due to the difficulties experienced by children with special needs to clean their teeth and mouth and the ability to understand instructions and age. Individuals ${ }^{10}$.

The ineffectiveness of sign language videos in improving dental and oral health maintenance is because sign language has weaknesses/ weaknesses, namely, it is less efficient because many signs must be learned, not all meanings can be hinted at especially abstract meanings and not everyone can understand sign language ${ }^{11}$. Also, children with hearing impairment will develop sign language according to their needs, therefore children with hearing impairment do not necessarily understand sign language developed in other special schools, they develop sign language based on the needs of their friendship to understand and understand each other. Although according to Samaranayake ${ }^{12}$ the advantage of the sign method is that it is following the world of deaf children, namely the world without sound, according to the ability of deaf children to receive and express thoughts through visual symbols according to their mother tongue.

The characteristics of the deaf in terms of speaking, emotional and social language, are not different from most people but have very low intelligence compared to most normal children, this is due to the limited ability of deaf people to interact through verbal language. The aspect of intelligence that comes from verbal is often difficult to understand, while language that comes from sight and movement will be easy to respond to. In communicating with each other, deaf children tend to use sign language (symbols), whereas, with normal people, deaf children tend to communicate using oral language by adjusting their age level ${ }^{6}$. This research is not in line with the theory that video media is very useful for specific groups and is good for training ${ }^{9}$.

Video is an appropriate medium to show examples of skills related to motion. With this tool, it is clarified either by slowing down or speeding up the displayed movement. However, the use of video media is only one way ${ }^{9}$.

\section{CONCLUSIONS AND SugGeSTIONS}

\section{CONCLUSION}

1. The different mean (mean) between the behavior of maintaining dental health in the pre-test condition and the behavior of maintaining dental health in the post-test condition. means that there are differences in the behavior of maintaining dental and oral health before and after the treatment of sign language video showing on the maintenance of dental and oral health. By showing an increase in the average score of behavior by 1 .

2. Screening of sign language videos was not effective in improving the maintenance of oral health in children with hearing impairment with a value of $\mathrm{p}=0.061$, meaning $p>0.05$.

\section{SUGGESTION}

1. For SLB institutions to make and apply brushing methods in UKS activities at schools which are held once a week.

2. For Puskesmas to be able to provide facilities for the Special School dental health program.

3. Further research is needed on other methods in improving oral health care behavior in children with hearing impairment.

\section{REFERENCES}

[1] Agusta, M, V, Ismail, A, Firdausy, M., D., Hubungan Pengetahuan Kesehatan Gigi dengan Kondisi Oral Hygiene Anak Tunarungu Usia Sekolah (Studi pada Anak Tunarungu Usia 712 Tahun di SLB Kota Semarang. Media Dental Intelektual Jurnal Volume 2 Edisi 1: hlm. 64-68.

[2] Forrest J O. 1995. Pencegahan Penyakit Mulut. Jakarta: Hipokrates: hlm. 38 - 70.

[3] Houwink, B, dkk. 1984. Ilmu Kedokteran Gigi Pencegahan. (melalui oleh Sutatmi Suryo). Yogyakarta: Gajah Mada University Press.

[4] Widasari, Dubita. Perbedaan Status Kesehatan Gigi dan Mulut pada Anak Tunarungu dengan Anak Tidak Tunarungu Usia 6-12 Tahun. UNEJ Digital Repository. (2014).

[5] Purohit, Bharathi M., Abhinav Singh. Oral Health Status of 12-year-old Children with disabilities and controls in Southern India. (Original Research). WHO South East Asia Journal of Public Health. Vol. 1(3). Pg. 330338. (2012).

[6] Husna, N., Prasko. 2019. Efektivitas Penyuluhan kesehatan gigi dengan menggunakan media Busy Book terhadap 
The Effectiveness of the Use of Sign Language Videos in Improving the Behavior of Dental and Oral Health Care in Children with Impairment in SLB Negeri 1 Jambi City, Indonesia

tingkat pengetahuan kesehatan gigi dan mulut. Jurnal Kesehatan Gigi Vol. 6 (2019) pg. 51-55.

[7] Mhaske M, Nazish B, dkk. 2012. Agen kimia dalam pengendalian plak gigi dalam kedokteran gigi: Gambaran umum tentang pengetahuan saat ini dan tantangan masa depan. Perpustakaan Penelitian Pelagia 3 (1): 268-272

[8] Roeslan, 2002, Imunologi Oral, Fakultas Kedokteran Universitas Indonesia, Jakarta

[9] Putri, N., L., 2012. Penggunaan Metode Bahasa lisan yang dikombinasikan dengan metode bahasa isyarat dalam upaya meningkatkan kemampuan berkomunikasi anak usia dini tunaganda 7-8 tahun. Jurnal Pendidikan dan
Pembelajaran, Volume 19, Nomor 1, April 2012, pg. 77-85.

[10] Mursita, R., A., 2015. Respon tunarungu terhadap penggunaan system bahasa isyarat Indonesia (SIBI) dan bahasa isyarakat Indonesia (BISINDO) dalam komunikasi. Jurnal Inklusi, Vol. 2, No. 2, Juli-Desember 2015. Pg. 221-232.

[11] Hakim., Lukman., Samino., dkk. 2008. Kamus Sistem Isyarat Bahasa Indonesia. Edisi Kelima. Jakarta.Direktorat Pembinaan Sekolah Luar Biasa.

[12] Samaranayake, L. 2006. Mikrobiologi untuk Kedokteran gigi. Churchill Livingstone: Elsevier Limited. p. 255-284.

Citation: Ervon Veriza et al, "The Effectiveness of the Use of Sign Language Videos in Improving the Behavior of Dental and Oral Health Care in Children with Impairment in SLB Negeri 1 Jambi City, Indonesia”, International Journal of Research Studies in Medical and Health Sciences. 2021; 6(3): 3-8. DOI: https://doi.org/10.22259/ijrsmhs.0603002

Copyright: () 2021 Ervon Veriza et al, This is an open-access article distributed under the terms of the Creative Commons Attribution License, which permits unrestricted use, distribution, and reproduction in any medium, provided the original author and source are credited. 